DOI: 10.20472/EFC.2021.015.001

\title{
STEPAN BAHTEEV
}

Ural Federal University, Russian Federation

SOPHIA TURKANOVA

Ural Federal University, Russian Federation

ANDREY PUSHKAREV

Ural Federal University, Russian Federation

OLEG MARIEV

Ural Federal University, Russian Federation

\section{MODELLING THE INFLUENCE OF TOBIN'S Q AND CASH FLOWS ON THE CAPITAL INVESTMENTS OF RUSSIAN FIRMS}

\begin{abstract}
:
The relationship between investment and cash flow has been extensively studied since the mid-20th century. The aim of our study is to assess the impact of Tobin's ratio and cash flows on the capital investments of Russian companies. For econometric estimation we data on 206 Russian public companies traded on the Moscow Exchange from 2011 to 2020. We apply quantile regression to obtain more detailed results. The results of our study confirm the significance of the Tobin ratio and cash flow on capital investments. We observe these effects in all quantiles however their magnitude varies. This research is valuable and can be utilized by companies to maximize efficiency of their capital expenditures.
\end{abstract}

\section{Keywords:}

Tobin's Q, Russian firms, quantile regression, capital investments

JEL Classification: L25, M21 


\section{Introduction}

The relationship between investment and cash flow has been extensively studied since the mid20th century. One of the most notable papers on the Q-theory of investment is the paper by Fazzari, Hubbard and Petersen (1993). In this article, investment is evaluated as a function of Tobin's $Q$ and cash flow based on firm-level data. The authors found out that cash flow has a large impact on firms that may face financial constraints, which is an evidence of capital market weaknesses associated with information asymmetries.

The paper was followed by a number of other studies on the Q-theory of investment and cash flows, however, the mechanisms of the influence of cash flow on investments are still controversial, especially in developing markets.

Tobin's ratio is the ratio of the market value of a company to its replacement value, that is, to the amount of money for which the company's existing assets could be fully reproduced. The ratio is a means of assessing whether an asset is overvalued or undervalued.

The aim of our study is to assess the impact of Tobin's ratio and cash flows on the capital investments of Russian companies. We suggest that such research is valuable and can be utilized by companies to maximize efficiency of their capital expenditures.

The rest of the paper is organized as follows. In the next section, we present a theoretical background of the research as well as previous findings described in the literature. In Section 3 data and methodology are described, results are presented in Section 4. Section 5 concludes.

\section{Theoretical background and literature review}

In the seminal paper, which investigates the relationship between Tobin's $Q$ and investments (Fazzari, Hubbard and Petersen, 1988, hereafter FHP), the authors estimated the investment model as a function of Tobin's $Q$ and cash flow using firm-level data. The authors suggest that some firms do not have sufficient access to external capital markets to respond to changes in capital prices, asset prices, or tax investment incentives. The limitation of the ability to raise funds from outside leads to the fact that investment costs depend on the availability of domestic financing, that is, investments are highly sensitive to cash flows. Assuming that Tobin's $Q$ may not properly reflect the investment opportunities of firms, various authors began to conduct studies aimed at eliminating this issue.

For example, Schaller (1990) in his study notes the unsatisfactory empirical performance of qinvestment models based on aggregated data. The results of the work show that data aggregation is the cause of incorrect specification and biased estimates of adjustment costs. Thus, it is noted that firm-level data is the best fir for the existing model.

Oliner, Rudebusch and Sichel (1995) evaluate and compare 6 investment models by the criterion of forecasting efficiency. In particular, the authors supplement the existing set of models in the literature with two Euler equations, which describe the optimal fixed capital of a firm for making an investment decision. Among the evaluated models, there is also the Tobin's $Q$ model. The results of the study show that predictive efficiency of models based on the Euler equations is inferior to other models, despite the theoretical assumptions to the contrary. However, Euler's equation is applicable under the assumption that capital markets are perfect. In the presence of financial constraints, the Euler equation cannot function, since it takes into account financial variables (Whited, 1992). 
Cooper and Ejarque (2001) argue that the assumption of a strictly concave profit function that reflects market power is sufficient to reproduce the results of q-investment theory. The paper, in contrast to the FHP hypothesis, does not take into account the presence of any capital market failures, while it is noted that the statistical significance of profit in the investment model is associated with the market power of firms, and not with the imperfection of the capital market. The authors conduct their research based on data for 400 firms over a 50-year period. Cooper and Ejarque also use the model to explain the differences in results for firms by size, since the literature suggests that larger firms are less constrained. The evaluation procedure shows the same concavity of profit for large and small firms. In the case of small firms, the authors find an increased investment response to profit streams.

Although the marginal value of $Q$ should summarize the effects of all factors influencing investment decisions, most studies show significance of cash flow in models. For example, Erickson and Whited (2000) believe that this error can be caused by an error in the measurement of the marginal $Q$. The authors test the hypothesis that investments by firms with limited liquidity are highly responsive to cash flow. As a result, they find no evidence that cash flows are relevant to the Tobin's $Q$ model of influence on investment, regardless of the presence of financial constraints.

The article by Jonathan Levellen and Katharina Levellen (2016) is a new attempt to study the relationship between investment and cash flow. To do this, the authors use data on the United States of America firms for the period from 1971 to 2009. The originality of the study lies in the use of a new way of measuring cash flow, which is the sum of income before certain expenses and depreciation. The results obtained by the authors show that cash flow not only correlates with Tobin's $Q$, but also explains investment well. The results also illustrate that financial constraints and limited free cash flow seriously affect investment decisions.

Overall, one can see that Tobin's $Q$ theory is still a topic for a discussion and there has not been uniform answer if it is applicable in all of the cases. Our research aims to test the theory for Russian firms, representing firms in the developing markets.

\section{Data and Methodology}

Tobin's $Q$ theory is rather straightforward. To calculate Tobin's $Q$ of a firm, it's necessary to calculate the firm's fair value as follows:

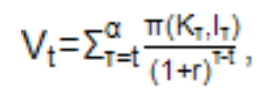

where $\pi$ is profit, $K_{T}$ is value of capital, $L_{T}$ are investments, $r$ is discount rate.

Then, the ratio of the received company value to the firm's replacement value is calculated. The result is the Tobin's Q (Tobin, 1969):

$$
Q_{t}=\frac{V_{t}}{K_{t}}=\frac{\sum_{T=t}^{\alpha} \frac{\pi\left(K_{T}, T_{T}\right)}{(1+r)^{T-t}}}{K_{t}} .
$$

If $Q>1$, the firm is attractive for investment. While $Q=1$, investors do not care whether to invest in this firm or not, since such investment does not carry any advantages or disadvantages compared to other assets. $Q<1$ means that the company should sell its capital, since this situation indicates its ineffective use. If the assumptions of the Modigliani-Miller theorem (1958) are met, in other words capital structure does not affect future profits. 
In our study, we use data on 206 Russian public companies traded on the Moscow Exchange from 2011 to 2020. All data used is taken from the financial statements of the companies.

Below, in the Table 1, the descriptive statistics are presented. It is clearly notable, that the standard deviations of values are high. This can be explained by the small size of the Russian market and can be characterized by presence of very large monopoly companies in the oil, gas and financial industries, and relatively small companies in other industries. This situation, as expected, led to the presence of heteroscedasticity in the models, therefore, robust errors are used further.

Table 1 - Descriptive statistics

\begin{tabular}{|l|l|l|l|l|l|}
\hline Variable & $\begin{array}{l}\text { No. of } \\
\text { observations }\end{array}$ & Mean & $\begin{array}{l}\text { Standard } \\
\text { deviation }\end{array}$ & Min & Max \\
\hline q & 811 & 1.632 & 1.730 & 0.002 & 9.956 \\
\hline cf & 764 & 101.111 & 275.780 & -50.8 & 2599 \\
\hline return & 675 & -0.025 & 0.571 & -9.784 & 0.75 \\
\hline cash & 782 & 59.155 & 254.674 & 0.001 & 3363 \\
\hline
\end{tabular}

Source: Own estimations based on financial statements data

The models we use in this study are based on the ones proposed by J. Lewellen \& K. Lewellen (2016). We also improve upon the original idea of the authors by utilizing quantile regression, which allows accounting for the firm size. Thus, we will sequentially evaluate three models.

Our regression equations are presented below:

$$
\text { capex }_{i, t}=a_{i, t}+\beta_{1} q_{i, t-1}+\beta_{2} C F_{i, t}+\varepsilon_{i, t} \text {, }
$$

where $\mathrm{q}_{\mathrm{i}, \mathrm{t}-1}-$ value of $\mathrm{Q}$ at time $\mathrm{t}-1$ of firm $\mathrm{i}, \mathrm{CF}$ - cash flow at time $\mathrm{t}$ of firm $\mathrm{i}, \varepsilon_{\mathrm{i}, \mathrm{t}}-$ error term;

$$
\text { capex }_{i, t}=\alpha_{i, t}+\beta_{1} q_{i, t-1}+\beta_{2} C F_{i, t}+\beta_{4} \text { return }_{i, t}+\beta_{5} \text { return }_{i, t-1}+\beta_{6} \text { return }_{i, t-2}+\varepsilon_{i, t} \text {, }
$$

where return $n_{i, t}-$ annual stock return of firm i at time $t-n(n=0,1,2)$;

$$
\begin{aligned}
\text { capex }_{\mathrm{i}, \mathrm{t}} & =\mathrm{a}_{\mathrm{i}, \mathrm{t}}+\beta_{1} \mathrm{q}_{\mathrm{i}, \mathrm{t}-1}+\beta_{2} \mathrm{CF}_{\mathrm{i}, \mathrm{t}}+\beta_{3} \mathrm{CF}_{\mathrm{i}, \mathrm{t}-1}+\beta_{4} \text { return }_{\mathrm{i}, \mathrm{t}}+\beta_{5} \text { return }_{\mathrm{i}, \mathrm{t}-\mathrm{1}}+ \\
& +\beta_{6} \text { return }_{\mathrm{i}, \mathrm{t}-2}+\beta_{7} \text { cash }_{\mathrm{i}, \mathrm{t}-1}+\beta_{8} \text { debt }_{\mathrm{i}, \mathrm{t}-1}+\varepsilon_{\mathrm{i}, \mathrm{t}}
\end{aligned}
$$

where $\operatorname{cash}_{\mathrm{i}, \mathrm{t}-1}-$ cash of firm $\mathrm{i}$ at time $\mathrm{t}-1$, debt $_{\mathrm{i}, \mathrm{t}-1}-$ debt of firm i at time $\mathrm{t}-1$.

The first model is the most basic one, taking into account the Tobin's $Q$ lag (as it commonly used in the literature) and cash flow as the only regressors.

Model 2 adds annual stock returns and two lags. We choose this approach, as we want to check what impact the profitability of the company has on the investment opportunities for investors. Accounting for the lags allows us to check whether the results of the past periods affect investment capabilities of the company.

Model 3 has been extended to include lags in cash flow, debt, and free cash. We suggest that capital investment response to these factors may be delayed.

To evaluate the models, we use the OLS and quantile regression. Quantile regression is a nonparametric technique that estimates the linear relationship between the explanatory variables and the specified quantiles of the dependent variable. Thus, we do not model the expected value 
of the dependent variable, instead assuming a linear relationship between any quantile of the dependent variable and the regressors. The advantage of this approach is a higher stability in a presence of outliers and in case of violation of the assumptions about the normal distribution of errors. Quantile regression expands results obtained via OLS, as it allows us to see how the influence of factors differs depending on the value of the dependent variable and to reveal heteroscedasticity.

\section{$4 \quad$ Results}

The results of the evaluation of the first model are presented in the Table 2 . We can observe that the coefficient of the Tobin's $Q$ lag is significant both when using the OLS and for each of the quantiles. However, it should be noted that the higher the quantile, the closer the coefficient estimate to zero. In other words, it can be argued that with higher capital expenditures, the influence of Tobin's $Q$ on investment decreases. For cash flow, we also get results that indicate the significance of its impact on capital investment. At the same time, here we see the opposite picture of the Tobin's $Q$ lag estimates: for higher quantiles, the coefficient is larger. It goes in line with the common sense higher cash flow allows firm to spend more on investments.

\section{Table 2 - The estimation results (Model 1)}

\begin{tabular}{|c|c|c|c|c|c|c|}
\hline \multirow{2}{*}{$\begin{array}{c}\text { Explanatory } \\
\text { variables }\end{array}$} & \multicolumn{6}{|c|}{ Dependent variable: Capital expenditures } \\
\hline & OLS & $\begin{array}{c}\text { Quantile } \\
10 \%\end{array}$ & $\begin{array}{c}\text { Quantile } \\
25 \%\end{array}$ & $\begin{array}{c}\text { Quantile } \\
50 \%\end{array}$ & $\begin{array}{c}\text { Quantile } \\
75 \%\end{array}$ & $\begin{array}{c}\text { Quantile } \\
90 \%\end{array}$ \\
\hline $\begin{array}{l}\text { Tobin's Q (t- } \\
\text { 1) }\end{array}$ & $\begin{array}{r}-7.660^{* * *} \\
(1.383)\end{array}$ & $\begin{array}{r}-5.290^{* * *} \\
(0.234)\end{array}$ & $\begin{array}{r}-3.539 * * * \\
(0.781)\end{array}$ & $\begin{array}{r}-2.956^{* * *} \\
(0.600)\end{array}$ & $\begin{array}{r}-1.215^{\star *} \\
(0.601)\end{array}$ & $\begin{array}{r}-1.051^{* *} \\
(0.407)\end{array}$ \\
\hline Cash flow & $\begin{array}{l}0.667^{* * *} \\
(0.0437)\end{array}$ & $\begin{array}{l}0.367^{* * *} \\
(0.0353)\end{array}$ & $\begin{array}{l}0.451^{* * *} \\
(0.0277)\end{array}$ & $\begin{array}{l}0.617^{* * *} \\
(0.0350)\end{array}$ & $\begin{array}{l}0.735^{\star * \star} \\
(0.0430)\end{array}$ & $\begin{array}{l}0.938^{* * *} \\
(0.0266)\end{array}$ \\
\hline Constant & $\begin{array}{r}2.495 \\
(3.163)\end{array}$ & $\begin{array}{r}0.700^{* * *} \\
(0.116)\end{array}$ & $\begin{array}{r}0.813 \\
(0.701)\end{array}$ & $\begin{array}{c}1.504^{\star * *} \\
(0.511)\end{array}$ & $\begin{array}{l}1.328^{* *} \\
(0.533)\end{array}$ & $\begin{array}{l}1.845^{*} \\
(1.043)\end{array}$ \\
\hline $\begin{array}{l}\text { No. of } \\
\text { observations }\end{array}$ & 520 & 520 & 520 & 520 & 520 & 520 \\
\hline R-squared & 0.904 & & & & & \\
\hline
\end{tabular}

Source: Own estimations based on financial statements data

Note: Robust standard errors in parentheses, ${ }^{* * *} p<0.01,{ }^{* *} p<0.05,{ }^{*} p<0.1$

Based on the results of evaluating Model 2 (Table 3 ), we find out that our conclusions on the Tobin's $Q$ lag and cash flow remained the same. The coefficient for the annual stock return turned out to be insignificant only for the $90 \%$ quantile, for all other quantiles and for the whole dataset, the coefficient is significant and negative, in other words, the higher the return on stocks, the less the Russian firms want to invest in capital. If the profitability is high, then the shareholders of the firm are satisfied, probably, that is why the management does not make decisions to increase capital investments, and instead, the cash flow can be directed to the payment of dividends. Such approach is common in Russia

\section{Table 3 - The estimation results (Model 2)}




\begin{tabular}{|c|c|c|c|c|c|c|}
\hline \multirow{2}{*}{$\begin{array}{c}\text { Explanatory } \\
\text { variables }\end{array}$} & \multicolumn{6}{|c|}{ Dependent variable: Capital expenditures } \\
\hline & OLS & $\begin{array}{c}\text { Quantile } \\
10 \%\end{array}$ & $\begin{array}{c}\text { Quantile } \\
25 \%\end{array}$ & $\begin{array}{c}\text { Quantile } \\
50 \%\end{array}$ & $\begin{array}{c}\text { Quantile } \\
75 \%\end{array}$ & $\begin{array}{c}\text { Quantile } \\
90 \%\end{array}$ \\
\hline $\begin{array}{l}\text { Tobin's Q (t- } \\
\text { 1) }\end{array}$ & $\begin{array}{r}-8.463^{* * *} \\
(1.872)\end{array}$ & $\begin{array}{r}-7.124^{* * *} \\
(1.031)\end{array}$ & $\begin{array}{r}-4.107^{* * *} \\
(1.144)\end{array}$ & $\begin{array}{r}-2.913^{* * *} \\
(0.633)\end{array}$ & $\begin{array}{r}-2.162^{* *} \\
(0.946)\end{array}$ & $\begin{array}{l}-1.280^{*} \\
(0.652)\end{array}$ \\
\hline Cash flow & $\begin{array}{l}0.647^{\star \star *} \\
(0.0499)\end{array}$ & $\begin{array}{l}0.370^{\star * *} \\
(0.0315)\end{array}$ & $\begin{array}{l}0.409^{* * *} \\
(0.0312)\end{array}$ & $\begin{array}{l}0.558^{* * *} \\
(0.0465)\end{array}$ & $\begin{array}{l}0.724^{\star * *} \\
(0.0561)\end{array}$ & $\begin{array}{l}0.955^{\star * *} \\
(0.0655)\end{array}$ \\
\hline $\begin{array}{l}\text { Annual stock } \\
\text { return }\end{array}$ & $\begin{array}{r}-21.20^{* *} \\
(9.210)\end{array}$ & $\begin{array}{r}-9.409^{* * *} \\
(2.159)\end{array}$ & $\begin{array}{r}-6.041^{* * *} \\
(1.850)\end{array}$ & $\begin{array}{r}-5.483^{\star * *} \\
(0.952)\end{array}$ & $\begin{array}{r}-5.491^{* *} \\
(2.372)\end{array}$ & $\begin{array}{l}-2.484 \\
(3.017)\end{array}$ \\
\hline $\begin{array}{l}\text { Annual stock } \\
\text { return }(t-1)\end{array}$ & $\begin{array}{r}-1.432 \\
(6.060)\end{array}$ & $\begin{array}{l}-2.607^{*} \\
(1.569)\end{array}$ & $\begin{array}{r}-2.474 \\
(1.518)\end{array}$ & $\begin{array}{r}-3.242^{* *} \\
(1.303)\end{array}$ & $\begin{array}{l}-1.541 \\
(1.681)\end{array}$ & $\begin{array}{l}-2.132 \\
(3.252)\end{array}$ \\
\hline $\begin{array}{l}\text { Annual stock } \\
\text { return (t-2) }\end{array}$ & $\begin{array}{r}-4.787 \\
(5.841)\end{array}$ & $\begin{array}{l}-0.736 \\
(1.475)\end{array}$ & $\begin{array}{r}-0.594 \\
(0.784)\end{array}$ & $\begin{array}{r}0.181 \\
(0.655)\end{array}$ & $\begin{array}{l}-1.693 \\
(1.087)\end{array}$ & $\begin{array}{r}0.722 \\
(2.321)\end{array}$ \\
\hline Constant & $\begin{array}{r}2.739 \\
(4.376) \\
\end{array}$ & $\begin{array}{r}1.396 \\
(1.305) \\
\end{array}$ & $\begin{array}{r}1.461^{*} \\
(0.885)\end{array}$ & $\begin{array}{l}1.997^{* *} \\
(0.864)\end{array}$ & $\begin{array}{l}2.318^{\star *} \\
(0.928)\end{array}$ & $\begin{array}{r}1.698 \\
(2.066) \\
\end{array}$ \\
\hline $\begin{array}{l}\text { No. of } \\
\text { observations }\end{array}$ & 360 & 360 & 360 & 360 & 360 & 360 \\
\hline R-squared & 0.894 & & & & & \\
\hline
\end{tabular}

Source: Own estimations based on financial statements data

Note: Robust standard errors in parentheses, ${ }^{* *} p<0.01,{ }^{* *} p<0.05,{ }^{*} p<0.1$

In the third model (Table 4), we added lags of cash flow, debt and cash. The addition of these variables made the coefficient for the yield for the $10 \%$ quantile insignificant, while the coefficient for the $90 \%$ quantile also remained insignificant. All second lags remained insignificant.

Table 4 - The estimation results (Model 3)

\begin{tabular}{|c|c|c|c|c|c|c|}
\hline \multirow{2}{*}{$\begin{array}{c}\text { Explanatory } \\
\text { variables }\end{array}$} & \multicolumn{6}{|c|}{ Dependent variable: Capital expenditures } \\
\hline & OLS & $\begin{array}{c}\text { Quantile } \\
10 \%\end{array}$ & $\begin{array}{c}\text { Quantile } \\
25 \%\end{array}$ & $\begin{array}{c}\text { Quantile } \\
50 \%\end{array}$ & $\begin{array}{c}\text { Quantile } \\
75 \%\end{array}$ & $\begin{array}{c}\text { Quantile } \\
90 \%\end{array}$ \\
\hline $\begin{array}{l}\text { Tobin's Q (t- } \\
\text { 1) }\end{array}$ & $\begin{array}{r}-8.223^{* * *} \\
(1.636)\end{array}$ & $\begin{array}{r}-4.678^{\star \star *} \\
(1.442)\end{array}$ & $\begin{array}{r}-5.837^{\star \star *} \\
(0.903)\end{array}$ & $\begin{array}{r}-5.232^{\star \star *} \\
(0.677)\end{array}$ & $\begin{array}{r}-2.617^{\star \star} \\
(1.092)\end{array}$ & $\begin{array}{r}-1.979^{* \star *} \\
(0.759)\end{array}$ \\
\hline Cash flow & $\begin{array}{l}0.305^{\star \star \star} \\
(0.0904)\end{array}$ & $\begin{array}{r}0.0683 \\
(0.0704)\end{array}$ & $\begin{array}{l}0.228^{* *} \\
(0.104)\end{array}$ & $\begin{array}{l}0.233^{\star * *} \\
(0.0771)\end{array}$ & $\begin{array}{r}0.425^{\star * *} \\
(0.105)\end{array}$ & $\begin{array}{l}0.443^{*} \\
(0.264)\end{array}$ \\
\hline $\begin{array}{l}\text { Cash flow (t- } \\
\text { 1) }\end{array}$ & $\begin{array}{c}0.222^{* *} \\
(0.0994)\end{array}$ & $\begin{array}{l}0.235^{\star \star *} \\
(0.0503)\end{array}$ & $\begin{array}{r}0.172 \\
(0.112)\end{array}$ & $\begin{array}{l}0.292^{* \star *} \\
(0.0400)\end{array}$ & $\begin{array}{l}0.284^{\star *} \\
(0.123)\end{array}$ & $\begin{array}{r}0.262 \\
(0.262)\end{array}$ \\
\hline $\begin{array}{l}\text { Annual stock } \\
\text { return }\end{array}$ & -11.68 & -3.097 & $-4.412^{* \star *}$ & $-4.775^{\star \star \star}$ & $-4.659^{\star \star \star}$ & -3.648 \\
\hline
\end{tabular}




\begin{tabular}{|c|c|c|c|c|c|c|}
\hline & $(7.817)$ & (2.992) & $(1.402)$ & $(1.160)$ & $(1.775)$ & $(4.079)$ \\
\hline $\begin{array}{l}\text { Annual stock } \\
\text { return }(\mathrm{t}-1)\end{array}$ & $\begin{array}{r}-12.74^{* *} \\
(5.413)\end{array}$ & $\begin{array}{l}-2.470 \\
(2.630)\end{array}$ & $\begin{array}{r}-1.823 \\
(1.352)\end{array}$ & $\begin{array}{r}-2.470 \text { ** } \\
(1.053)\end{array}$ & $\begin{array}{l}-2.867^{*} \\
(1.506)\end{array}$ & $\begin{array}{l}-4.379 \\
(3.393)\end{array}$ \\
\hline $\begin{array}{l}\text { Annual stock } \\
\text { return (t-2) }\end{array}$ & $\begin{array}{r}1.559 \\
(6.109)\end{array}$ & $\begin{array}{r}0.346 \\
(2.435)\end{array}$ & $\begin{array}{r}0.841 \\
(0.657)\end{array}$ & $\begin{array}{r}0.639 \\
(1.282)\end{array}$ & $\begin{array}{r}-1.415 \\
(1.338)\end{array}$ & $\begin{array}{r}0.843 \\
(3.031)\end{array}$ \\
\hline Cash $(\mathrm{t}-1)$ & $\begin{array}{r}0.476^{\star \star \star} \\
(0.100)\end{array}$ & $\begin{array}{l}-0.0285 \\
(0.0593)\end{array}$ & $\begin{array}{r}-0.0466 \\
(0.110)\end{array}$ & $\begin{array}{l}0.396^{\star *} \\
(0.164)\end{array}$ & $\begin{array}{l}0.340^{\star * *} \\
(0.0662)\end{array}$ & $\begin{array}{r}0.348^{* * x} \\
(0.118)\end{array}$ \\
\hline Debt (t-1) & $\begin{array}{r}-0.0250 \\
(0.0215)\end{array}$ & $\begin{array}{l}0.0572^{\star \star} \\
(0.0271)\end{array}$ & $\begin{array}{c}0.0420^{*} \\
(0.0222)\end{array}$ & $\begin{array}{r}-0.0157 \\
(0.0239)\end{array}$ & $\begin{array}{r}-0.0544^{* \star *} \\
(0.0156)\end{array}$ & $\begin{array}{r}-0.00679 \\
(0.0505)\end{array}$ \\
\hline Constant & $\begin{array}{r}0.655 \\
(4.215)\end{array}$ & $\begin{array}{r}-0.775 \\
(1.548)\end{array}$ & $\begin{array}{r}2.587^{\star \star *} \\
(0.876)\end{array}$ & $\begin{array}{r}2.851^{* * *} \\
(0.744)\end{array}$ & $\begin{array}{l}2.593^{\star *} \\
(1.035)\end{array}$ & $\begin{array}{r}5.050^{\star * *} \\
(1.800)\end{array}$ \\
\hline $\begin{array}{l}\text { No. of } \\
\text { observations }\end{array}$ & 323 & 323 & 323 & 323 & 323 & 323 \\
\hline R-squared & 0.940 & & & & & \\
\hline
\end{tabular}

Source: Own estimations based on financial statements data

Note: Robust standard errors in parentheses, ${ }^{* *} p<0.01,{ }^{* *} p<0.05,{ }^{*} p<0.1$

Cash flow lag is significant for $10 \%, 50 \%$ and $75 \%$ quantiles. In addition, in this case, the cash flow ratio for the $10 \%$ quantile is insignificant. Cash lag is significant for $50 \%, 75 \%$ and $90 \%$ quantiles. The debt lag is significant for the $10 \%, 25 \%$ and $75 \%$ quantiles. Hence, we can conclude that for smaller firms, debt financing of capital investments is more attractive than using their own free cash for investments. A logical explanation for this observation is the impossibility for smaller firms to rely fully on their own funds when updating their production facilities.

It is worth noting that the expanded model shows weakest results for $90 \%$ quantile: only the coefficients of the Tobin's $Q$ lag, cash flow and a constant are significant. This confirms the intuitive logic: the largest firms have sufficient funds to finance capital investments independently. Moreover, the relatively high value of the constant coefficient confirms that the largest firms will make capital investments independent of other factors, since they have large capital capacities that require constant renovation.

\section{Conclusion}

In this study, we have considered significance of the Tobin ratio and cash flow on the capital expenditures of Russian publicly traded firms. Since current state of research on the topic does not give definitive answer whether Tobin ratio can be actually used, we try to test this for the case of firms in a developing market of Russia.

We consider three models with varying degree of complexity. First considers only actual values of Tobin's $Q$ and cash flow, while other two take into account other firm performance indicators and their lagged values. Such approach allows us to paint a bigger picture and consider dynamics of main indicators rather than their values just at one point in time. 
Analyzed literature suggests that significance of the Tobin ration may vary depending on the size of the company. To test this hypothesis and address possible heteroscedasticity concerns we employ quantile regression, where quantiles are determined based on the capital expenditures.

The results of our study confirm the significance of the Tobin ratio and cash flow on capital investments. We observe these effects in all quantiles however their magnitude varies. Namely, in all three models, weakest effects are estimated for the $90 \%$ quantile, and, in general the higher the quantile, the closer the coefficient estimate to zero. It would suggest that for firms with higher capital expenditures same value of the Tobin's $Q$ would reflect smaller change in their capital investments. Financial analysts when using Tobin ratio should consider this fact.

For cash flow, on the other hand, magnitude of its effects is higher for firms with higher capital expenditures. Our results are consistent across all three models. Adding more lagged indicators as controls seem to improve explanatory power of the model and allowed us to estimate the effects of the main predictors more accurately.

There are several limitations to this study. First, we consider only publicly traded companies, which in case of Russia, is only a small share of the market. Additionally, these are, in most cases, larger companies. Therefore, our study cannot be generalized for all Russian firms of different sizes. Second, we consider only one approach to estimating fair value and one investments model. Further studies can improve upon that.

Overall, our findings confirm results that has been previously published for firms in developed countries, and can be used by financial analysts and companies themselves.

\section{Acknowledgments}

Research was supported by the grant of the Russian Science Foundation № 19-18-00262 "Empirical modelling of balanced technological and socioeconomic development in the Russian regions".

\section{$7 \quad$ References}

COOPER, R., EJARQUE, J. (2001) Exhuming Q: Market Power vs. Capital Market Imperfections. NBER Working Paper No. 8182.

ERICKSON, T. and WHITED, T.M. (2000) Measurement Error and the Relationship between Investment and q Journal of Political Economy, vol. 108, no. 5

FAZZARI, S.; HUBBARD, R. G. and PETERSEN, B. C. (1987) Financing constraints and corporate investment. 1987.

LEWELLEN, J. and LEWELLEN, K. (2016) Investment and cash flow: New evidence. Journal of Financial and Quantitative Analysis. 2016, Vol. 51(4), s. 1135-1164.

MODIGLIANI, F. and MILLER, M. H. (1958) The cost of capital, corporation finance and the theory of investment. The American economic review. 1958, Vol. 48, No. 3, s. 261-297.

OLINER S.; RUDEBUSCH G. and SICHEL D. (1995) New and Old Models of Business Investment: A Comparison of Forecasting Performance. Journal of Money, Credit and Banking, 1995, Vol. 27, s. 806-826.

TOBIN, J. (1969) A general equilibrium approach to monetary theory. Journal of money, credit and banking. 1969, Vol. 1, No. 1., s. 15-29. 
SCHALLER, H. (1990) A re-examination of the q theory of investment using us firm data. Journal of applied econometrics. 1990, Vol. 5, No. 4, s. 309-325.

WHITED, T. M. (1992) Debt, liquidity constraints, and corporate investment: Evidence from panel data. The Journal of Finance. 1992, Vol. 47, No. 4, s. 1425-1460. 